\title{
The Middle Caddoan Period in the Big Cypress Creek Drainage Basin
}

Bo Nelson

Heritage Research Center, Stephen F. Austin State University

Mike Turner

Follow this and additional works at: https://scholarworks.sfasu.edu/ita

Part of the American Material Culture Commons, Archaeological Anthropology Commons, Environmental Studies Commons, Other American Studies Commons, Other Arts and Humanities Commons, Other History of Art, Architecture, and Archaeology Commons, and the United States History Commons

Tell us how this article helped you.

This Article is brought to you for free and open access by the Center for Regional Heritage Research at SFA ScholarWorks. It has been accepted for inclusion in Index of Texas Archaeology: Open Access Gray Literature from the Lone Star State by an authorized editor of SFA ScholarWorks. For more information, please contact cdsscholarworks@sfasu.edu. 


\section{The Middle Caddoan Period in the Big Cypress Creek Drainage Basin \\ Creative Commons License \\ (c) (1) \& 8}

This work is licensed under a Creative Commons Attribution-NonCommercial 4.0 International License 
The Middle Caddoan Period in the Big Cypress Creek Drainage Basin

\section{Bo Nelson and Mike Turner}

The Middle Caddoan period in the Big Cypress Creek drainage basin has been based upon a synthesis of Thurmond's (1990) archaeological overview of the basin. Thurmond defines a transitional Caddoan period (dating ca. A.D. 1300-1400) from 14 sites that have ceramic assemblages combining Early Caddoan and Late Caddoan stylistic attributes. A review of these sites, along with additional information from recent archaeological investigations (e.g., Kotter et al. 1993), suggests that the Middle Caddoan period in the Big Cypress Creek basin has an evolving cultural diversity that extends over a longer period of time, fitting well with Story's (1990) definition of the period as dating from ca. A.D. 12001400 .

Although there is an absence of documented subsistence evidence and few radiocarbon dates (only seven from four sites), there are recognizable distinctions that may be made about Middle Caddoan period settlement patterns, mortuary practices, and the material culture record in the basin (Table 1). Based on these observations (discussed below), and the currently available archaeological record, 38 sites in the Big Cypress Creek drainage basin may now be classified as belonging to the Middle Caddoan period (Figure 1).

Most of these sites are located in the extreme western portions of the basin in the vicinity of mounds (Z.V. Davis-McPeek, 41UR4/99) and mound complexes (Keith, 41TT11, and Hale, 41TT12) that date to either the Early or Middle Caddoan period. The majority of the sites $(n=23)$ represent small settlements (farmsteads and hamlets), but there are recognizable larger sites covering several acres (41CP15, 41CP230, 41TT110, and HSSkiles [no trinomial]).

Twenty-two of the 38 sites (see Figure 1) are small cemeteries or are habitation sites with an associated family burial ground containing less than 10 individuals; these burials usually have small amounts of grave goods. The grave goods often appear to be age and/or gender specific (e.g., miniature vessels, pipes, and arrow points), with children or adolescents sometimes buried along side the adults. There are also reports of deep shaft burials (some with multiple interments) along Greasy Creek, but as there are several Middle Caddoan cemeteries in this area (41CP3, 41UR1, 41UR17, and 41UR21), the exact locations are unknown; descriptions of some of the burials, along with photographs of some of the grave goods, do exist, however.

It is the ceramic sherds and vessels from these settlements and cemeteries that the greatest distinctions may be made between the known Middle Caddoan period sites in the Cypress Creek basin. The comparison of ceramic assemblages from Middle Caddoan sites within the basin document at least three spatial and/or temporal groupings. These groups are best characterized by differences in the proportions of such decorative techniques as red slipping, brushing, and engraving (see Table 1).

The first group of sites contain identifiable vessels of Sanders Plain, Sanders Engraved, and Canton lncised. These are associated in burials with plain jars and small bowis, and if accompanied by a water bottle, the bottle is usually more elaborately engraved. The engraved designs include solid or cross-hatched pendant triangles around lines; vertical or horizontal zones divided by ladders or cross-hatching, with the zones sometimes filled with the same or alternating circular or rectangular designs. Other vessels have decorative elements of diagonal incising, cross-hatched pendant triangles, rows of punctations (often parallel), and engraved ladders. Rims are straight to slightly thickened with some lip notching, and some rims contain from two to four tabs or lugs. Vertical scalloping of the 


\section{Table 1. Characteristics of the Middle Caddoan Period in the Cypress Creek Basin}

\section{CFIRAMICS}

\section{GROUP 1}

\section{Identifiable Types:}

Sanders Plain

Sanders Engraved

Canton Incised

Effigy Vessels

Undecorated small Bowls \& Jars

\section{GROUP 2}

Sanders Engraved

Canton Incised

Haley Engraved

Maxey Noded Redware

Pease Brushed-Incised

Rattlesnake Motif

La Rue Neck Banded

Undecorated small Bowls \& Jars

\section{GROUP 3}

Canton Incised

Haley Engraved

Pease Brushed-Incised

Rattlesnake Motif

La Rue Neck Banded

\section{DECORATION TECHNIQUES:}

pendant triangles (solid \& cross-hatched) diagonal lines (engraved \& incised) vertical \& horizontal zones of ladders or cross-hatching circular designs; rectangular designs

punctations (often in parallel rows); applique (small amounts)

scalloped rims (vertical \& horizontal); rim tabs (two to four) lugs (two to four) rim punctations

red slipping (large amounts)

brushing (very small amounts if presenrt)

engraved designs icrease in varieties \& amounts

horizontal \& vertical scrolls; ladders

pendant triangles (small solid \& large cross-hatched)

punctating; applique; neck-banding; decorative straps (all increase)

red-slipping still in large amounts some with scroll engravings

Vesseis begin to resemble the shapes, manufacture, and contain designs similar and with some elements like those better known in Late Caddoan brushing becomes dominant decorating technique red slipping ( very small amounts)

Calibrated C14 DATES in the Cypress Basin

41TT11 (AD 1309-1356); (AD 1383-1445)

41TT372 (AD 1216-1283); (AD 1306-1365); (AD 1337-1394)

41UR133 (AD 1295-1455)

41UR142 (AD 1160-1292) 


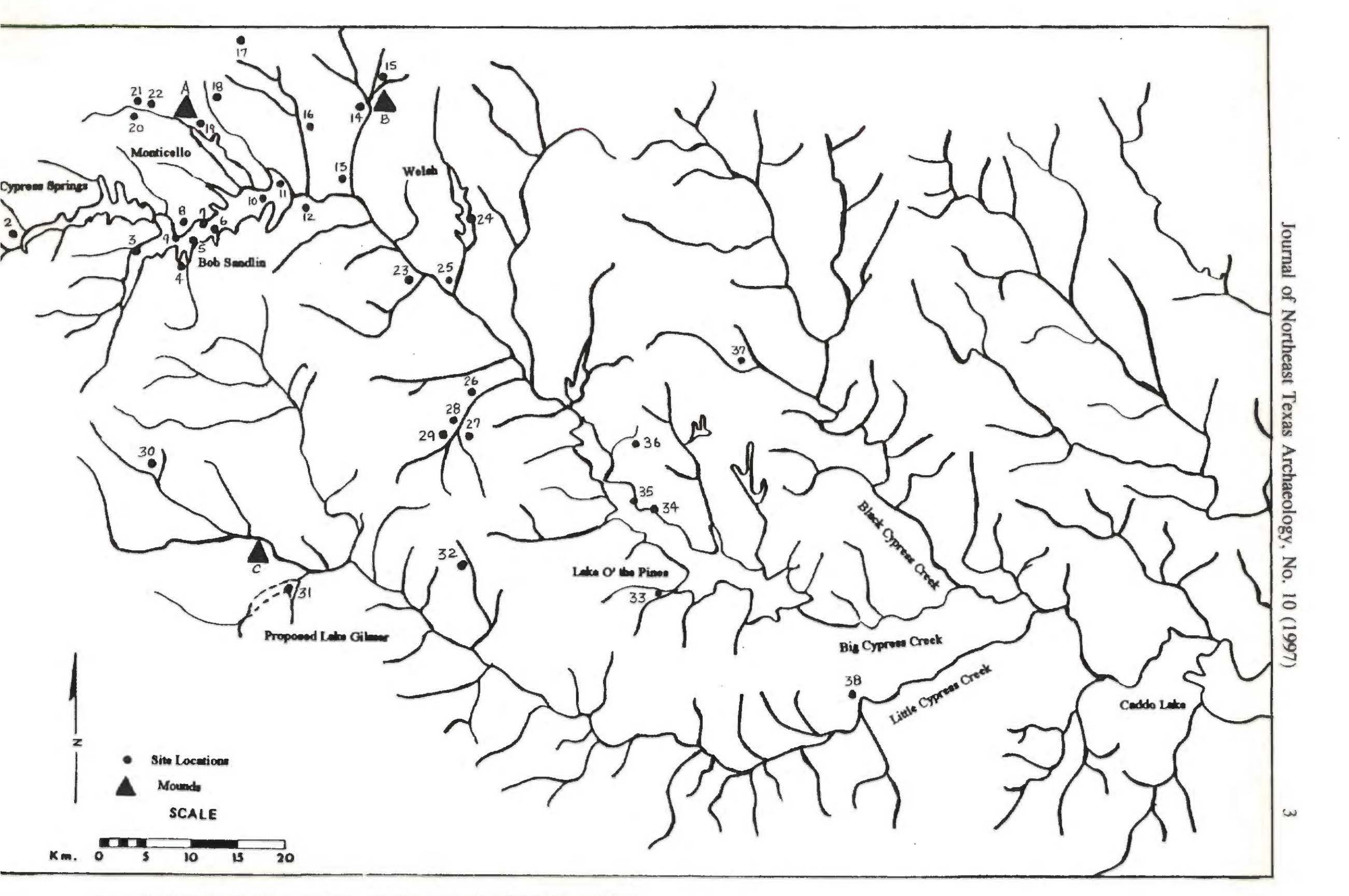


KEY: Middle Caddoan Sites in the Cypress Creek Drainage Basin.

\begin{tabular}{|c|c|c|c|c|c|}
\hline 1. & 41FK4 & & 20. 41 FK 70 & $C$ & $S S$ \\
\hline 2. & $41 \mathrm{FK} 7$ & SS & 21. 41 FK 66 & & SS \\
\hline 3. & $41 F K 32$ & $S S$ & 22. 41 FK 65 & & SS \\
\hline 4. & $41 C P 230$ & $L S$ & 23. $41 \mathrm{CP} 10$ & C & SS \\
\hline 5. & 41CP16 & $S S$ & 24. $41 \mathrm{TT} 226$ & $C$ & $S S$ \\
\hline 6. & 41CP39 & SS & 25. TT-Swanano & C & \\
\hline 7. & 41TT110 & $L S \quad R$ & 26. $41 \mathrm{CP} 3$ & C & SS \\
\hline 8. & $41 \mathrm{TT} 310$ & $S S$ & 27. 41UR17 & C & \\
\hline 9. & 41TT115 & $S S$ & 28. 41UR1 & C & \\
\hline 10. & $41 C P 47$ & $S S$ & 29. 41UR21 & $C$ & \\
\hline 11. & 41TT121 & SS & 30. 41UR142 & & $S S$ \\
\hline 12. & 41CP15 & LS & 31. 41UR133 & & SS \\
\hline 13. & 41TT52 & $S S$ & 32. 41UR8 & C & \\
\hline 14. & 41TT14 & $S S$ & 33. $41 \mathrm{MR} 6$ & C & \\
\hline 15 . & 41TT36 & $S S$ & 34. MR-Big Oaks & $C$ & \\
\hline 16. & $41 \mathrm{TT} 650$ & $S S$ & 35. 41MR63 & C & \\
\hline 17. & 41TT372 & SS & 36. MR-Anjo & C & \\
\hline 18. & 41TT135 & $S S$ & 37. CS-Hay & $C$ & \\
\hline 19. & 41TT16 & $S S$ & 38. HS-Skiles & C & $L S$ \\
\hline & $\begin{array}{l}\text { Cemetery } \\
\text { Small Settlement } \\
\text { Large Settement } \\
\text { Rattlesnake Motif }\end{array}$ & & . & & \\
\hline
\end{tabular}

MOUNDS
A. $41 \mathrm{TT} 12$
L.A. Hale
Early Caddoan
B. 41TT11
George L. Keith
Middle Caddoan
C. 41UR4/99 Z.V. Davis / McPeek
Early Caddoan 
rim is also noted, along with scalloping extending horizontally out from the mouth of the vessel (Figures 2-4). While ceramic sherd counts will have large amounts (up to 30-40\%) of undecorated red-slipped wares, the most distinguishing characteristic of the first group is the absence of brushing as a decorative treatment. Sites included in the first group include: 41CP16, 41CP39, 41CP47, 41FK4, 41FK7, 41FK32, 41FK65, 41FK70, 41TT135, 41TT372, and 41TT650 (see Figure 1).

The second group of Middle Caddoan sites have Sanders Engraved, Canton Incised, Maxey Noded Redware, Haley Engraved, Pease Brushed-Incised, and vessels with the engraved rattlesnake motif (see Turner, this volume). Many bowls and jars remain undecorated, but engraved vessels are more common. Decorative elements include ladders, horizontal and vertical scrolls, circular lines and branches, large cross-hatched pendant triangles, and repeating paneled triangular and circular motifs, along with the red-slipping of some engraved vessels (see Figures 2-4). While vessels with punctations, applique, neck-banding, and decorative straps occur in noticeable amounts, red slipping remains common (up to 20-30\%). Brushing becomes one of the dominant decorative techniques, occurring in frequencies between 25-40\%. The following sites in the Big Cypress Creek basin are included in the second group: 41CP10, 41CP15, 41CP230, 41TT11, 41TT14, 41TT16, 41TT36, 41TT52, 41TT110, 4ITT115, 41TT121, 41TT226, TT-Swanano, 41UR133, and 41UR142 (see Figure 1).

The ceramics associated with the third group show, more than do the other two groups, closer stylistic relationships with the subsequent Late Caddoan period in the Big Cypress Creek basin. There is increased brushing (30-50\%) in the ceramic assemblages, while red slipped pottery becomes a minor component (less than 5\%). Vessels begin to have the shapes, the manufacturing techniques, and the designs very similar to those found in the better known Late Caddoan types (Figures 5-7). The engraved rattlesnake motif is still present (see Figure 7d), however, along with Pease Brushed-Incised and Haley Engraved, and engraved ceramics increase in amount and diversity in this third group of Middle Caddoan period sites. Sites included in the third group include the following: 41CP3, CSHay, HS-Skiles, 41MR6, 41MR63, MR-Big Oaks, MR-Anjou, 41UR1, 41UR8, 41UR17, and 41UR21 (see Figure 1; see also Turner, this volume).

\section{References Cited}

Kotter, S. M., R. Rogers, R. Taylor, K. Reese-Taylor, and W. P. Glander

1993 Archaeological Investigations within the Monticello B-2 First Five-Year Disturbance Area, Titus County, Texas. Espey, Huston \& Associates, Inc., Austin.

Story, D. A.

1990 Cultural History of the Native Americans. In The Archeology and Bioarcheology of the Gulf Coastal Plain, by D. A. Story, J. A. Guy, B. A. Burnett, M. D. Freeman, J. C. Rose, D. G. Steele, B. W. Olive, and K. J. Reinhard, pp. 163-366. 2 Vols. Research Series No. 38. Arkansas Archeological Survey, Fayetteville.

Thurmond, J. P.

1990 Archeology of the Cypress Creek Drainage Basin, Northeastern Texas and Northwestern Louisiana. Studies in Archeology 5. Texas Archeological Research Laboratory, The University of Texas at Austin. 

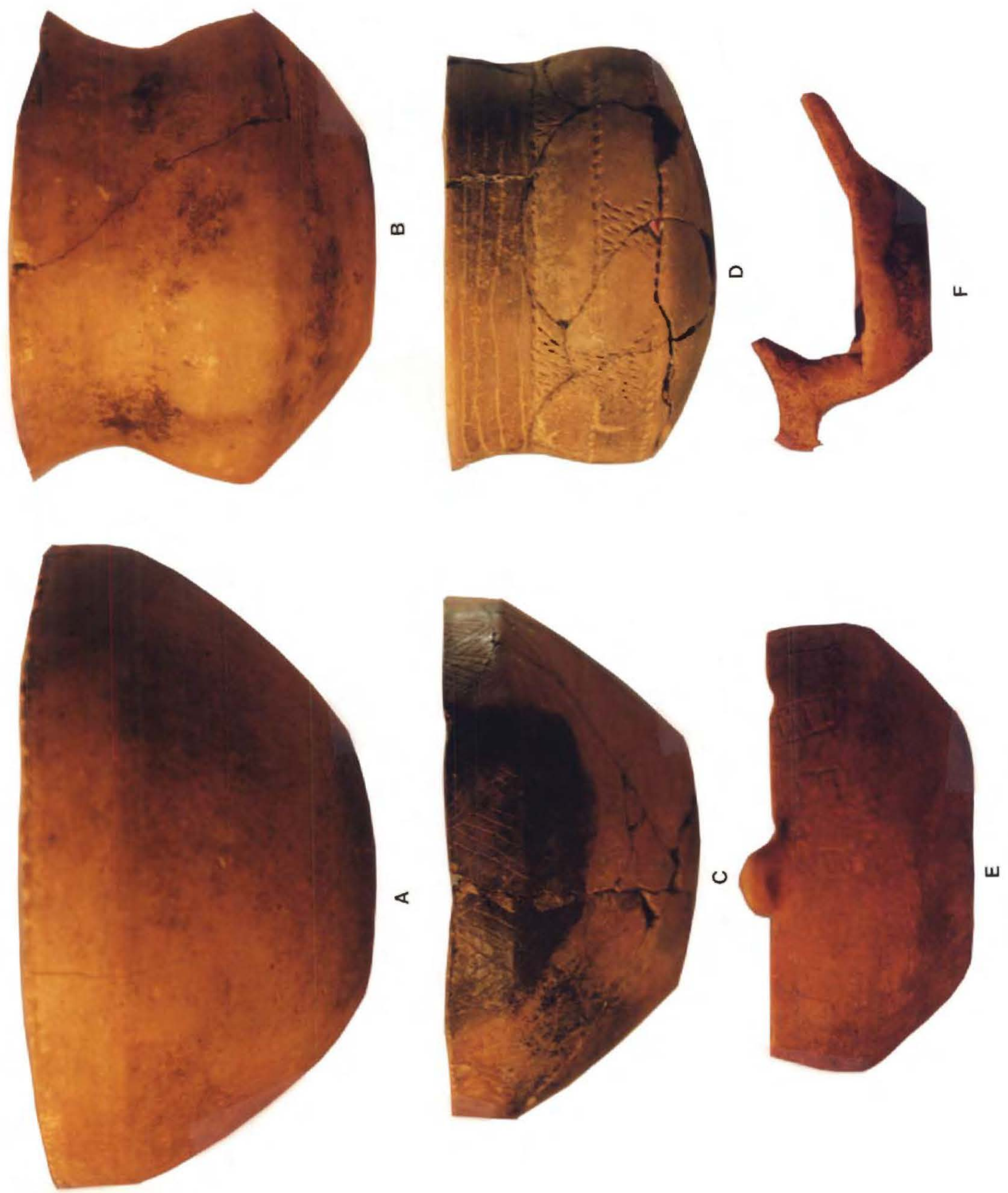

Figure 2. Group 1 and 2 Vessels: a-b, plain bowls; c-e, engraved bowls; f, effigy bowl. 


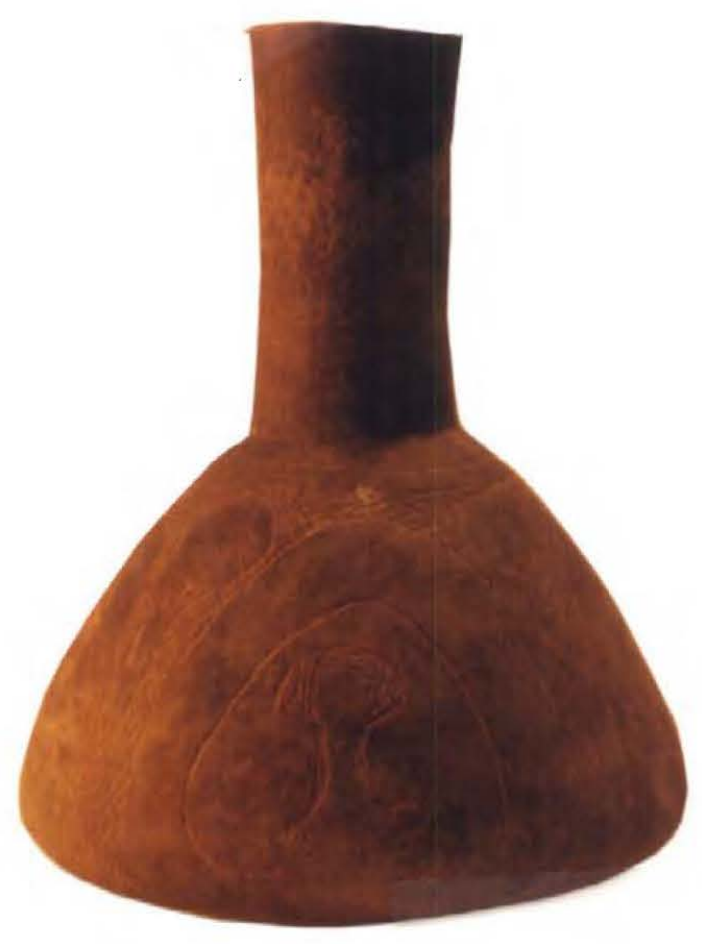

A

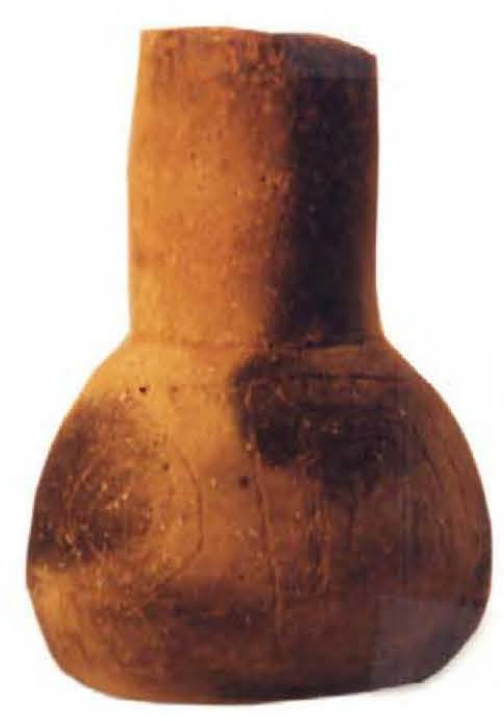

B

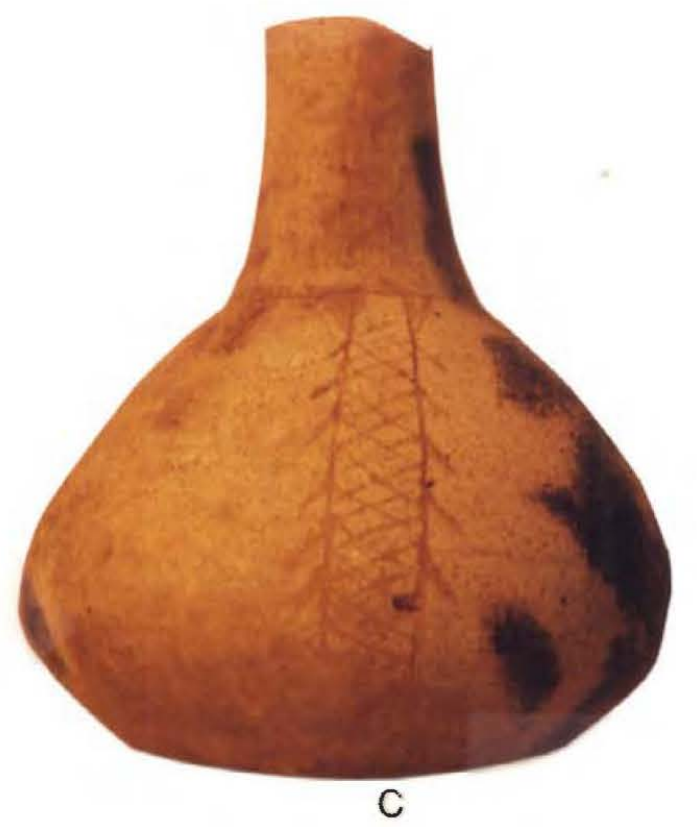

Figure 3. Group 1 and 2 Engraved Bottles. 


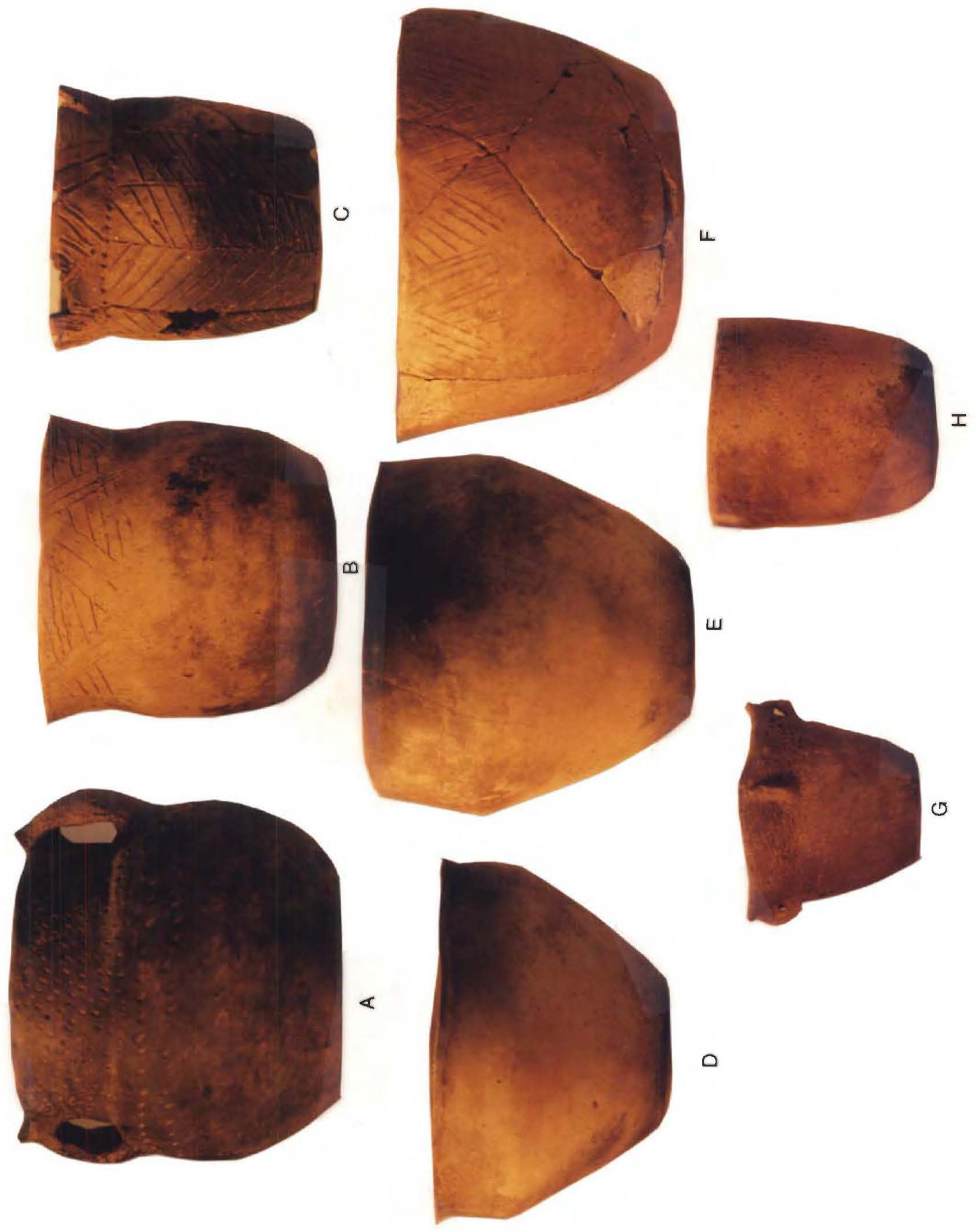

Figure 4. Group 1 and 2 Incised, Punctated, and Plain Bowls and Jars. 


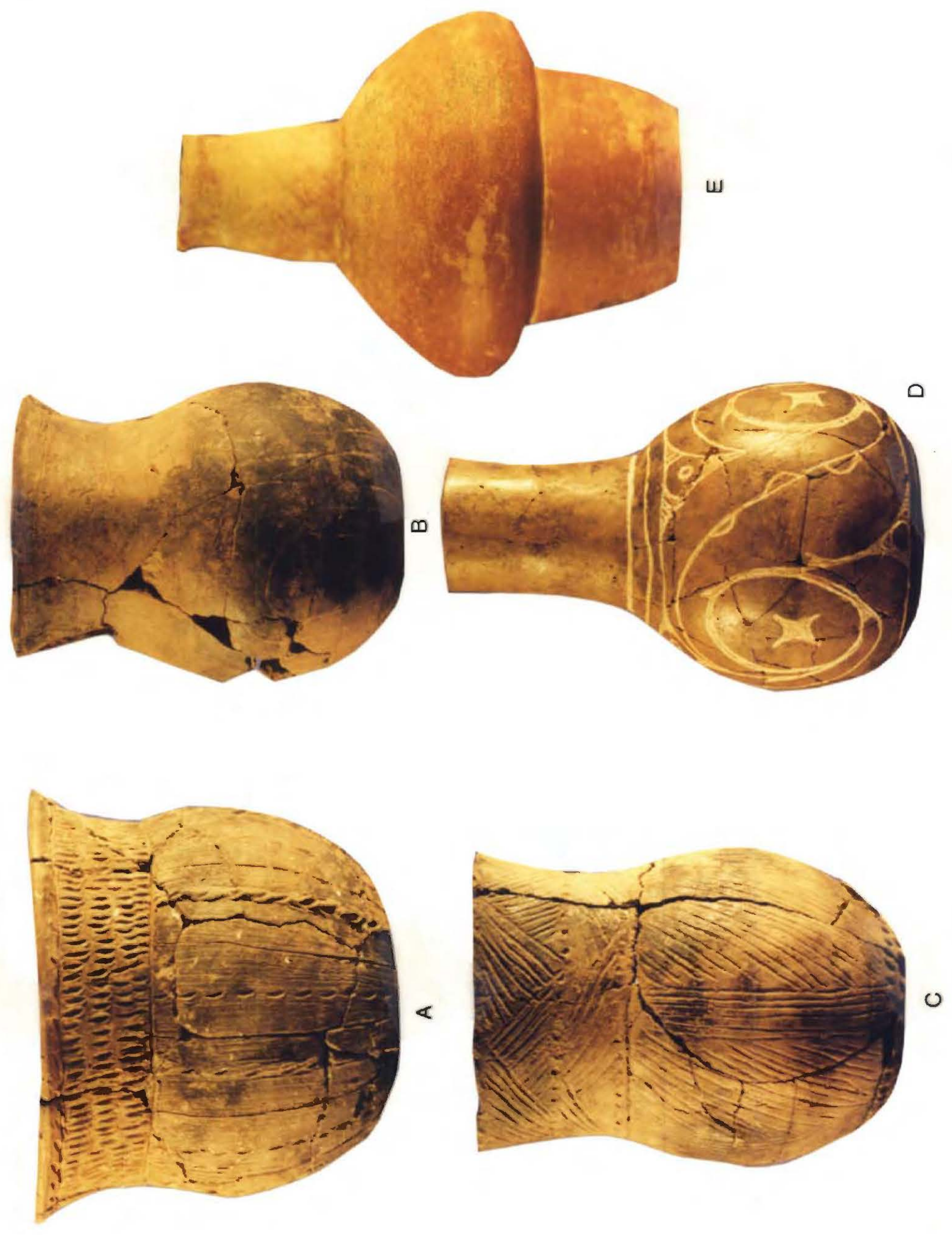

Figure 5. Group 3 Vessels: a-c, jars; d, Haley Engraved; e, slipped bottle. 


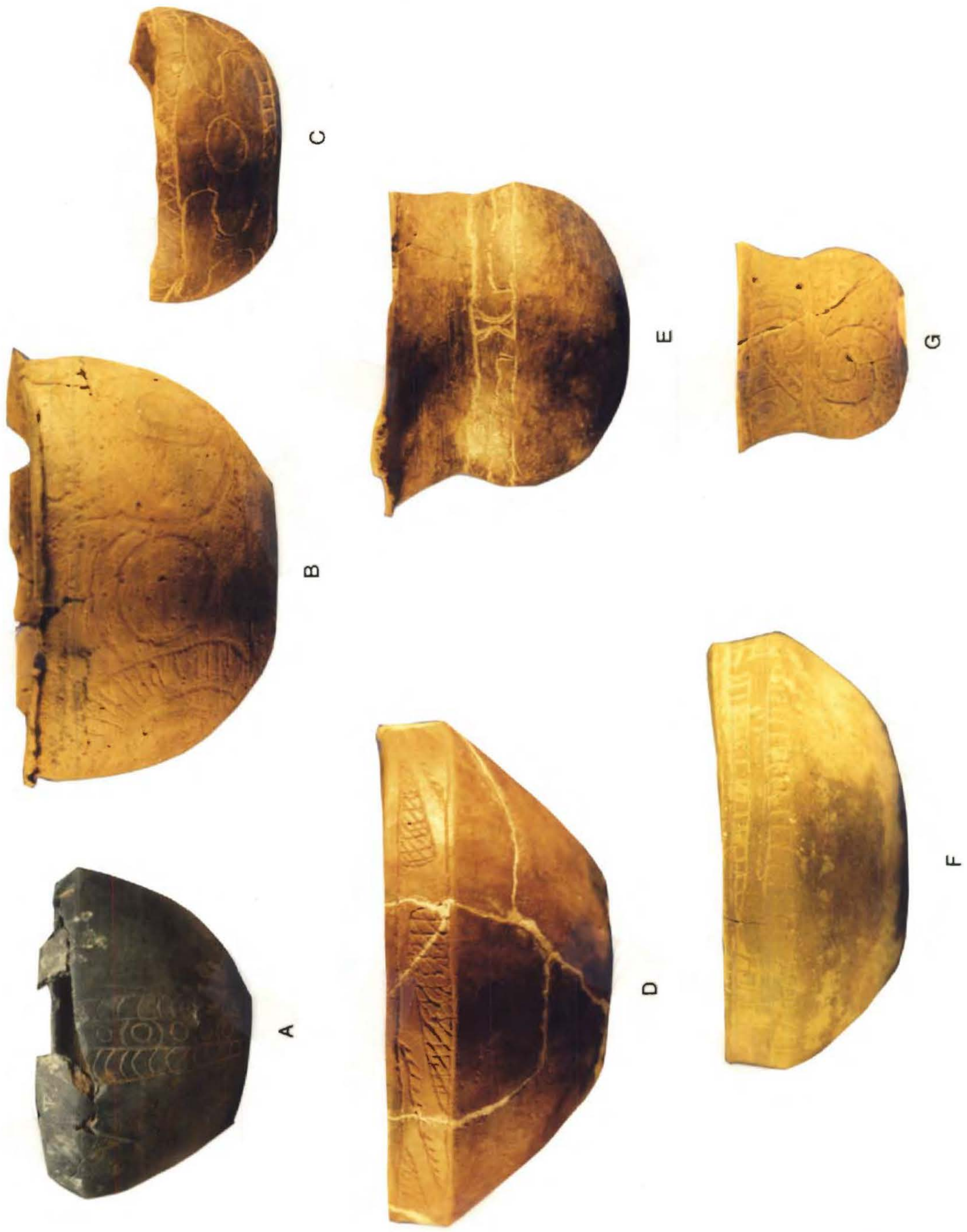

Figure 6. Group 3 Engraved Bowls. 

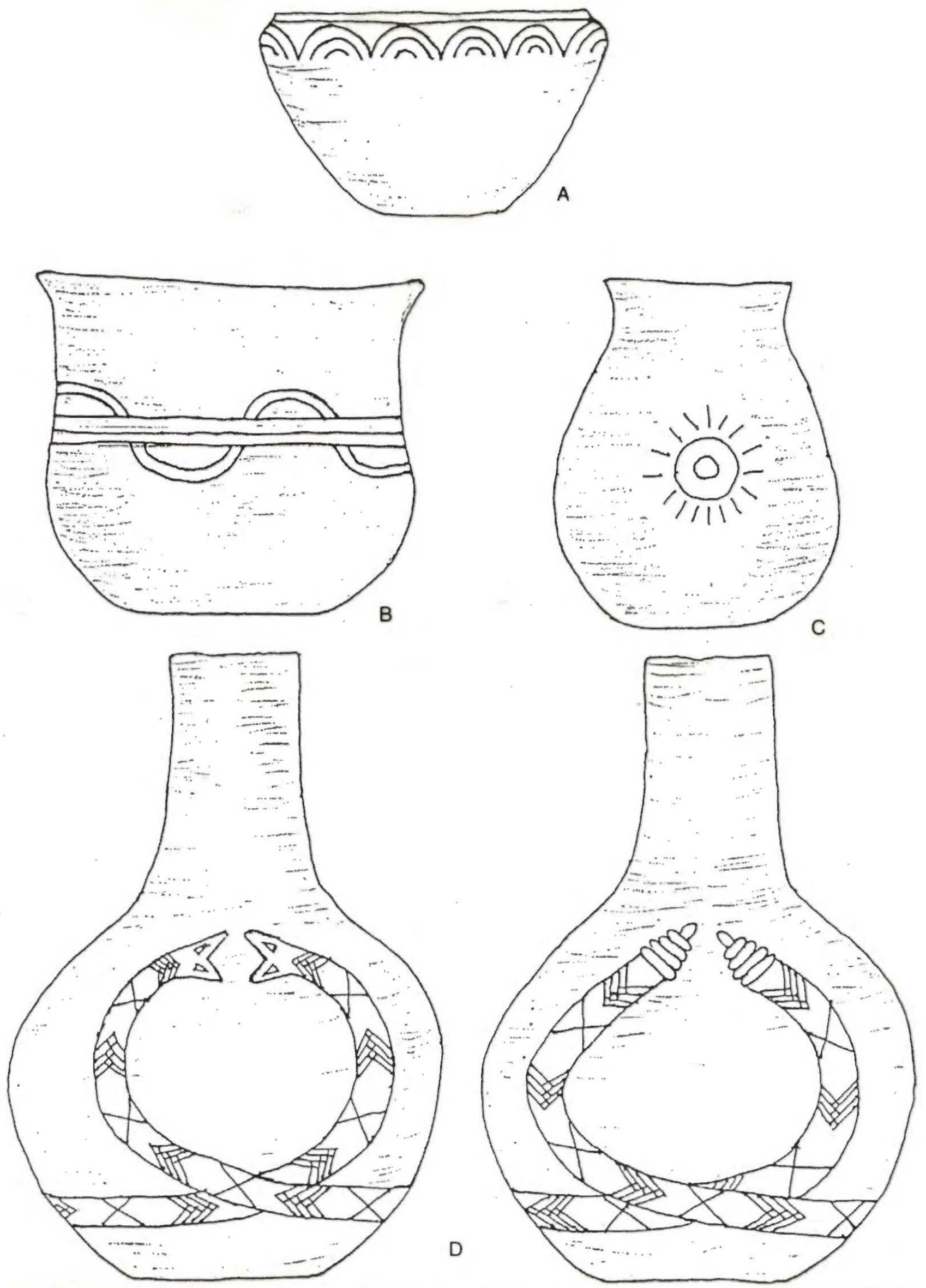

Figure 7. Group 3 Engraved Bowls and Bottle with Engraved Rattlesnake Motif. 